\title{
A constructive review of the State Forest Inventory in the Russian Federation
}

\author{
Alexander Alekseev ${ }^{1 * \dagger}$, Erkki Tomppo ${ }^{2,3}$, Ronald E. McRoberts ${ }^{4^{*} \dagger}$ (D) and Klaus von Gadow ${ }^{5,6}$
}

\begin{abstract}
The State Forest Inventory (SFI) in the Russian Federation is a relatively new project that is little known in the English-language scientific literature. Following the stipulations of the Forest Act of 2006, the first SFI sample plots in this vast territory were established in 2007. The 34 Russian forest regions were the basic geographical units for all statistical estimates and served as a first-level stratification, while a second level was based on old inventory data and remotely sensed data. The sampling design was to consist of a simple random sample of 84,700 circular 500 $\mathrm{m}^{2}$ sample plots over forest land. Each sample plot consists of three nested concentric circular subplots with radii of 12.62, 5.64 and $2.82 \mathrm{~m}$ and additional subplots for assessing and describing undergrowth, regeneration and ground vegetation. In total, 117 variables were to be measured or assessed on each plot.

Although field work has begun, the methodology has elicited some criticism. The simple random sampling design is less efficient than a systematic design featuring sample plot clusters and a mix of temporary and permanent plots. The second-level stratification is mostly ineffective for increasing precision. Qualitative variables, which are not always essential, are dominant, while important quantitative variables are under-represented. Because of very slow progress, in 2018 the original plan was adjusted by reducing the number of permanent sample plots from 84,700 to 68,287 so that the first SFI cycle could be completed by 2020 .
\end{abstract}

Keywords: Forest inventory, Sampling design, Stratification, Remote sensing, Bias, Accuracy

\section{Introduction}

Russian forests comprise approximately $22 \%$ of the total forest area of the world and provide a wide range of goods and services including timber, energy and non-wood forest products. At the same time, the future of this vast resource is subject to major environmental and development issues that include conservation of biological diversity, the effects of climate change and sustainable livelihoods. Considerable public interest and political will are directed towards the sustainable use of Russian forests and provide the motivation and rationale for monitoring progress towards the objective of strategic sustainability.

\footnotetext{
* Correspondence: a_s_alekseev@mail.ru; mcrob001@umn.edu

${ }^{+}$Alexander Alekseev and Ronald E. McRoberts contributed equally to this work.

${ }^{1}$ Department of Forest Inventory, Management and GIS, Saint-Petersburg State Forest Technical University, Institutsky per., 5, 194021 Saint-Petersburg, Russia

${ }^{4}$ Northern Research Station, USDA Forest Service, 1992 Folwell Avenue, Saint Paul, MN 55108, USA

Full list of author information is available at the end of the article
}

The earliest comprehensive review of global forest resources, including a quantitative description and valuation of forest products and a review of ownership and sustainable use, was published by the U.S. Forest Service in 1910 (Zon 1910). The Food and Agriculture Organization of the United Nations (FAO) initiated the first World Forest Assessment (FAO 1948). The assessment was initially recommended by the Conference of FAO in 1945 and conducted during 1947 and 1948, and the report was published in 1948. Later decisions were to undertake World Forest Assessments every five years (Holmgren and Persson 2002).

The first national forest inventories (NFI) were established in the Nordic countries to assess quantities of available wood: Norway (1919-1930), Finland (1921-1924) and Sweden (1923-1929) (Tomppo et al. 2010a). The United States of America followed in 1928. Multiple other European countries have had NFIs since the 1960s, China and the Republic of Korea in the Asian region since the 1970s, and India since the 1980s. Canada designed a new plot-based NFI in the late 1990s, and Brazil began 
planning for a sample-based NFI in 2005 (Tomppo et al. 2010a). FAO continues to assist in the development of sample-based forest inventories and monitoring programs in many Latin American and African countries. Increasing information needs and emerging environmental issues have led to a gradual widening of the scope of NFIs. Today, NFIs based on sound statistical approaches are widely used to assess a country's forest resources and to support policy making and both national and international reporting.

In Russia, a forest inventory based on statistical principles was first used in 1925 to estimate the wood resources in the floatable area of the river Luga in the Leningrad region (Table 1). The objective was to evaluate the practicability and profitability of timber harvesting and transportation by waterways for industrial and export purposes. This first Russian application of statistical principles to forest inventory was at approximately the same time as in Finland and Sweden. The sampling design was based on parallel lines separated by distances of $4,8,16$ or $32 \mathrm{~km}$. Visual estimates were obtained for $4 \mathrm{~km} \times 10 \mathrm{~m}$ transects that could be assessed in a single working day. At the end of each $4 \mathrm{~km}$ tract, all trees with diameters of at least $8 \mathrm{~cm}$ were callipered for two 10 $\mathrm{m} \times 100 \mathrm{~m}$ sample plots. A maximum statistical error of $10 \%$ was recognized as sufficiently precise for estimates of mean area and growing stock volume based on sample plots and tracts using area ratios.

Subsequent efforts focused on estimating forest wood resources for industrial purposes in the remote areas of Karelia and the Kola Peninsula as well as in the catchments of the Mezen and Pechora Rivers in the Komi Republic and the catchment of the Angara River in the Irkutsk region. During the period 1960-1970, forest inventories were conducted in the Ivanovo region in the European part of Russia. Parts of the Lithuanian forests were also assessed using a fairly modern methodology based on a regular grid of sample plots. During the period 1980-1990, forest inventories for remote areas in Siberia and the Far East using statistical methods based on photo samples and a limited number of terrestrial plots produced estimates with acceptable levels of accuracy (Alekseev 2013).

Statistically-based inventories in Russia have a long history of nearly one century (Table 1). During this time, basic forest inventory principles were developed in multiple countries and are now accepted internationally. More recently, the theory and practical application of statistical principles for international forest inventories have been widely discussed and published in textbooks (Kangas and Maltamo 2006; Köhl et al. 2006; Tomppo et al. 2011) and in the form of handbooks with specific guidance and instructions based on scientific principles (Lithuanian National Forest Inventory 2003; Bechtold and Patterson 2005; Federal Ministry 2006; Gabler and Schadauer 2008; FAO 2009).

The new Russian State Forest Inventory (SFI), based on Article No. 90 of the Forest Code of 2006, was initiated in 2007, and focuses on strategic rather than management objectives. It was initiated close in time to similar efforts in Canada and Brazil. Canada and the Russian Federation are similar with respect to environmental conditions and the large areas that must be inventoried. For example, the Canadian land area is estimated to be $9,984,670 \mathrm{~km}^{2}$ or $58.4 \%$ of the land area of the Russian Federation with $17,098,246 \mathrm{~km}^{2}$. In Russia, eight forest growing zones are distinguished of which at least three, tundra and low density taiga, taiga, and conifer-broadleaved forest zones, are also found in Canada. Approximately, 15 Canadian terrestrial ecozones coincide at least partially with the 34 Russian forest regions.

Table 1 History of statistically-based forest inventories in the Russian Federation (Alekseev 2013)

\begin{tabular}{lll}
\hline Year & Region of Russia (or former Soviet Union) & Area (ha) \\
\hline 1925 & Floatable district of the river Luga, Leningrad region & 241,438 \\
$1928-1929$ & Karelia Republic and Kola Peninsula & 8 million \\
1930 & Floatable district of river Mezen, Komi Republic & 10 million \\
1931 & Floatable district of river Pechora, Komi Republic & 21 million \\
1930 s & Floatable district of river Angara, Irkutsk region & 10 million \\
1960 s & Siberian exploitable forests & 20 million \\
1967 & Ivanovo region & 0.8 million ${ }^{1}$ \\
$1970 s$ & Lithuanian 18 forest enterprises & 1.5 million ${ }^{2}$ \\
1980 s & Photo statistical inventory of Siberian and Far Eastern forests & unknown \\
$1990 s$ & Siberian and Far Eastern forests inventory by key plots method & unknown \\
2007 & State forest inventory of forest land & in progress \\
\hline
\end{tabular}

${ }^{1}$ Fedosymov (1986)

${ }^{2}$ Antanaitis and Repshis (1973) 
The SFI sampling design features probability sampling, post-stratification to increase precision, a concentric circular sample plot configuration, a list of variables to be assessed, and specific precision requirements. Although field work began in 2007, the methodology has elicited some criticism. The objectives of this review were to describe the current methods, present a few selected first results, discuss issues of concern, and provide recommendations for improvement in the form of relevant concepts and general outlines of solutions. In particular, development of detailed solutions should be the subject of additional research conducted in conjunction with SFI personnel.

\section{Current methods}

\section{The Forest land}

The official land area of the Russian Federation is slightly less than 1.71 billion hectares (ha) and is distributed over six land classes: forest, water, bogs, arable land, built-up land and other land. For sample-based forest inventories, the population may be considered to consist of forest land within the area sampled. The SFI was originally planned for only forest land (891.16 million ha; see Fig. 1). Land areas outside forest land may possibly include patches of forest land but were not included in the lands to be inventoried.

For the SFI, forest land includes special sub-categories such as the land of the Forest Fund under the jurisdiction of the Federal Forest Service of Russia, special protected natural areas and urban areas (Fig. 1). The land area covered by forests under the jurisdiction of the Forest Fund is only $45.1 \%$, which is much less than the total forest land category which accounts for 69.2\% (Land Fund of the Russian Federation 2013). Land on which forests are found (land with forest) are classified as forest land or non-forest land. Forest land consists of two sub-categories: land covered by forest and land not covered by forest. Non-forest land includes areas unsuitable for forestry, special lands, agricultural land and waters. The same classification is used by all authorities that manage forests including the Ministry of Natural Resources and Ecology, the Ministry of Defense, the Municipal Administrations and others.

Areas of total forest land and its sub-categories represent important basic information to be estimated by means of forest inventories. Sub-categories include

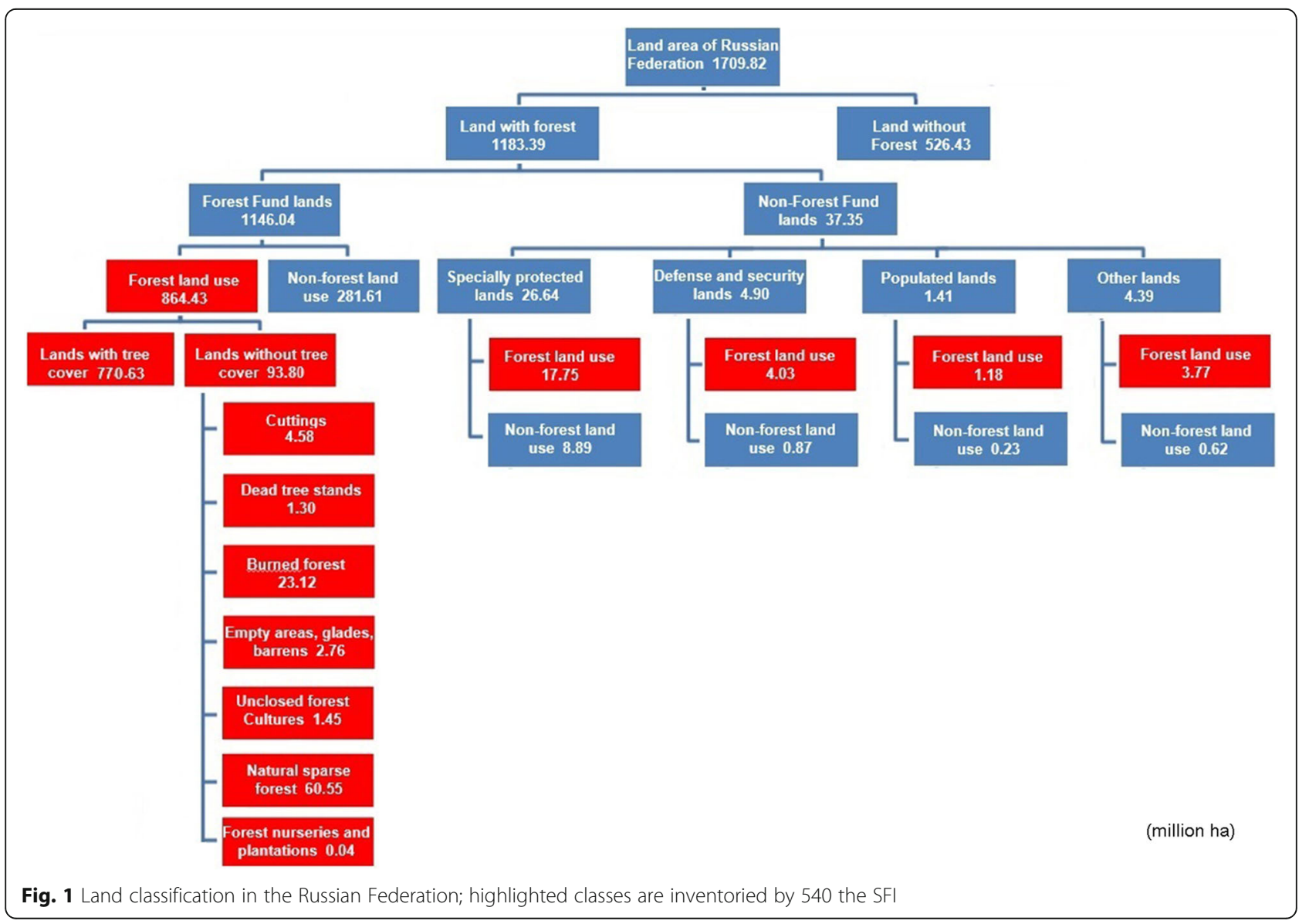


vegetation zones, soil types, site fertility classes, tree species dominance or stand age classes. In addition, knowledge of which forest areas have been and should be subject to specific silvicultural regimes, including nature conservation objectives, are of interest. Forest inventories often provide information about the areas of different land classes, such as the areas of arable land, urban areas, roads and other built-up areas, all of which should be considered in consultation with other national agencies concerned with land use assessments.

\section{Sampling design}

The SFI uses a two-level approach to stratification to facilitate separate estimation for different forest conditions. The first-level strata include the 34 Russian forest regions that were delineated according to climatic and topographic features (Table 2, Fig. 2).

The second level of stratification which was intended to increase precision used 49 strata defined with respect to age class, forest yield class, density class, land class, and species composition. These strata were delineated

Table 2 Forest regions of the Russian Federation (RF) and target precision values

\begin{tabular}{|c|c|c|}
\hline No. & Description of Forest Regions & Target precision for growing stock volume estimates (\%) \\
\hline 1 & Near tundra forest and low density taiga forest of the European-Ural part of the RF & 5 \\
\hline 2 & Northern taiga region of the European part of the RF & 3 \\
\hline 3 & Middle taiga region of the European part of the RF & 2 \\
\hline 4 & Southern taiga region of European part of RF & 1 \\
\hline 5 & Conifer-broadleaved (mixed) forest region of European part of RF & 1 \\
\hline 6 & Forest-steppe region of European part of RF & 2 \\
\hline 7 & Steppe region of European part of RF & 2 \\
\hline 8 & Desert and semi-desert region of European part of RF & 5 \\
\hline 9 & Northern Caucasus mountain forest region & 2 \\
\hline 10 & Northern Ural taiga region & 3 \\
\hline 11 & Middle Ural taiga region & 2 \\
\hline 12 & Southern Ural forest steppe region & 2 \\
\hline 13 & Western Siberian near tundra forest and low density taiga region & 5 \\
\hline 14 & Western Siberian northern taiga flat region & 3 \\
\hline 15 & Western Siberian middle taiga flat region & 2 \\
\hline 16 & Western Siberian southern taiga flat region & 2 \\
\hline 17 & Western Siberian near taiga forest steppe region & 2 \\
\hline 18 & Middle Siberian near tundra and low density taiga region & 5 \\
\hline 19 & Middle Siberian flat taiga region & 4 \\
\hline 20 & Near Angara taiga region & 2 \\
\hline 21 & Middle Siberian near taiga forest steppe region & 2 \\
\hline 22 & Eastern Siberian near tundra forest and low density taiga region & 5 \\
\hline 23 & Eastern Siberian permafrost taiga region & 3 \\
\hline 24 & Altay-Sayansky mountain taiga region & 3 \\
\hline 25 & Altay-Sayansky mountain forest steppe region & 4 \\
\hline 26 & Baykal mountain forest region & 3 \\
\hline 27 & Over Baykal mountain permafrost region & 4 \\
\hline 28 & Over Baykal mountain forest region & 3 \\
\hline 29 & Over Baykal forest steppe region & 3 \\
\hline 30 & Far Eastern near tundra forests and low density taiga region & 5 \\
\hline 31 & Kamchatka taiga region & 3 \\
\hline 32 & Far Eastern taiga region & 3 \\
\hline 33 & Near Amur and Seaside conifer-broadleaved forest region & 2 \\
\hline 34 & Far Eastern forest steppe region & 2 \\
\hline
\end{tabular}




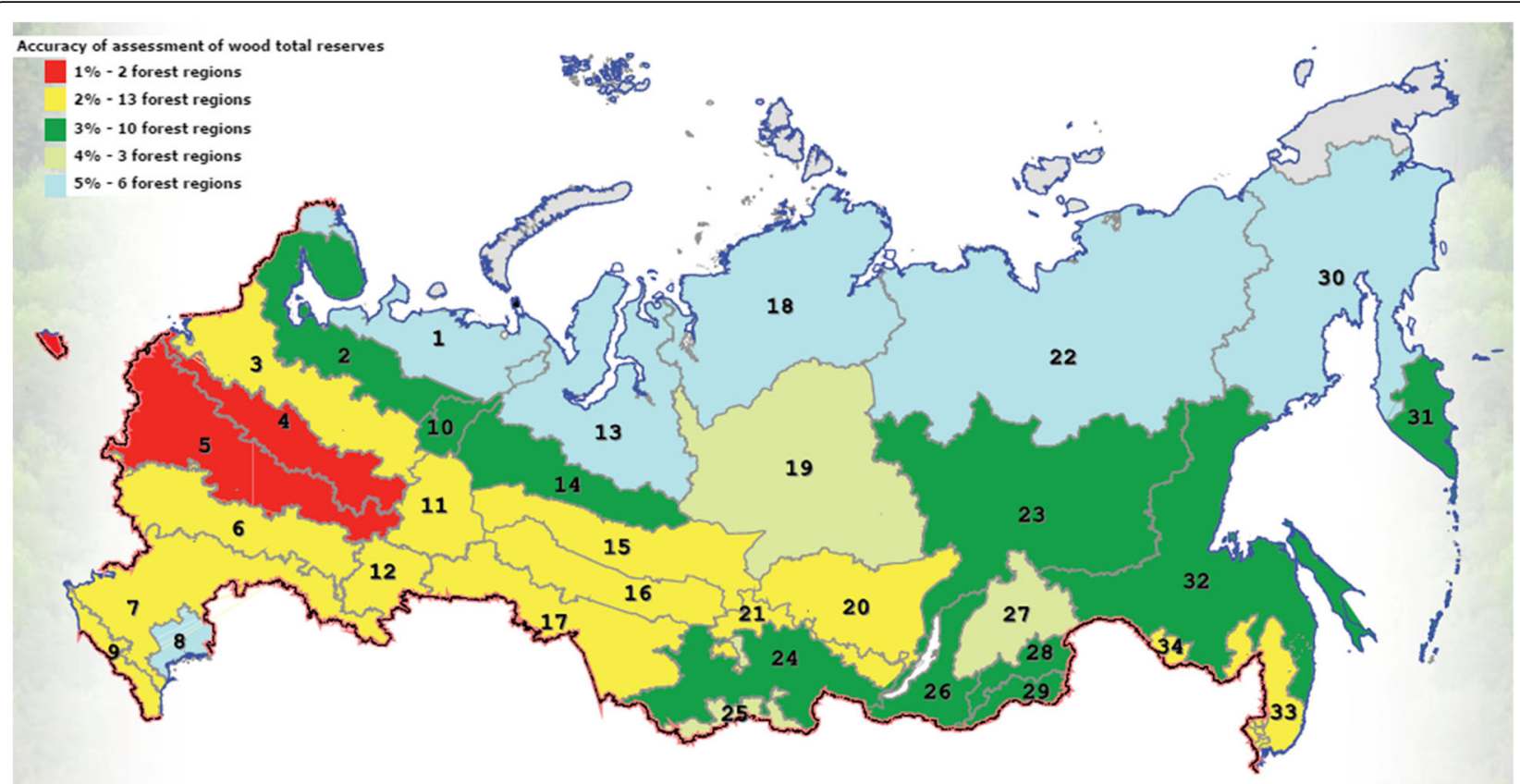

Fig. 2 Forest regions in the Russian Federation (see Table 2 for numbering scheme)

using information from previous forest management inventories, remotely sensed data with resolution of less than $5 \mathrm{~m}$, State forest registers, topographic maps, cartographic information on land management and current reporting on forest use, protection and reforestation (Fig. 3). A particular feature of the second-level stratification is that the entirety of each forest management compartment is assigned to the same stratum, regardless of any within-compartment variation.

During the years 2014-2016, the number of forest regions was increased from 34 to 41 regions.

A primary factor affecting sample size is the required precision of estimates. For the SFI, the target precisions for growing stock estimates ranged from 1 to $5 \%$, depending on region (Table 2). The sample sizes necessary to satisfy the precision requirements were calculated separately for each of the initial 34 forest regions (Fig. 2). Over the entire 891.16 million ha of forest land, 84,700 sample plots were to be established.

\section{Plot configuration and measurements}

Multiple factors are considered when selecting a plot configuration. First, NFIs typically use one of four plot types: 1) fixed radius plot, 2) concentric subplots, 3) angle count or Bitterlich plot, and 4) angle count plot with a maximum distance. Second, each measured tree should add new information. Beyond some threshold, each additional tree adds little new information and only increases the time necessary to complete the plot measurements. A basic criterion is that measurement of each

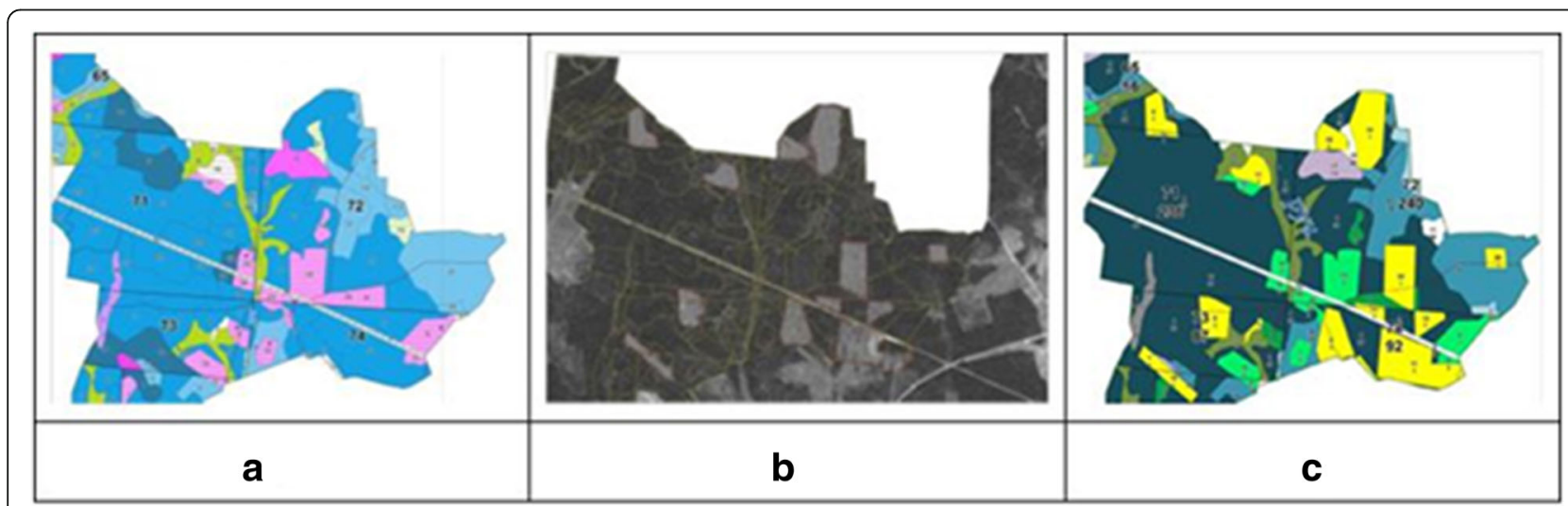

Fig. 3 Second-level stratification: a) forest management map colored by age and species, b) satellite image, c) strata map for inventory planning 
plot and/or each plot cluster should be completed in a single day. On the other hand, larger plots capture more tree-level information and facilitate use of remotely sensed data to increase precision. A balance between the principles of field inventory and the needs of remote sensing-assisted inventory should be sought.

The current standard SFI plot configuration represents a compromise among multiple planning objectives (Table 3). The $500 \mathrm{~m}^{2}$ sample plot consists of three concentric nested circular subplots with radii of 12.62, 5.64 and $2.82 \mathrm{~m}$. To avoid excessive measurements of small trees, each subplot had a different minimum diameter for trees to be measured. In addition, two circular plots with radius of $1.78 \mathrm{~m}$ were used to assess regeneration, and a $10 \mathrm{~m} \times 1 \mathrm{~m}$ strip plot was used to assess ground vegetation. Although this plot configuration is relatively common among temperate and boreal NFIs, its utility could be evaluated relative to changing lists of plot variables and differences between species-rich southern Russian forests and the more uniform northern forest ecosystems.

On all sample plots, all trees meeting minimum diameter thresholds are measured and mapped using special integrated equipment including data recorders with a global positioning system navigator, an electro-magnetic compass, a laser rangefinder, an electronic protractor for measuring angles, and an optical device for measuring diameters. All plots are permanent and are planned for remeasurement at regular intervals. Plots are permanently marked using special geodetic tools, and geographical coordinates are estimated using satellite navigation systems.

For each sample plot, 117 variables are assessed within seven blocks: (1) landscape, soil type, general tree stand description; (2) additional tree data including dead trees; (3) ground vegetation; (4) undergrowth and below canopy vegetation; (5) stumps and deadwood; (6) regeneration; and (7) biodiversity (Table 4). Trees whose data are used to construct stem profile models are selected and detailed measurements of stem form, wood quality and assortment structure are obtained.

Generally, the field team consists of at least three members, of whom one must be a forest engineer with higher education. Team members are usually permanent employees of the state forest inventory enterprises. Each team member has a specific area of expertise and responsibility. Before the start of the field work in early spring, all inventory teams undergo special training, ending with a performance test which must be passed in order to participate during the coming months of field work.

\section{Considerations for improvement}

Despite the historically solid theoretical and practical background for sample-based forest inventories in the Russian Federation (Fedosimov and Anisochkin 1979; Fedosimov 1986), multiple aspects of the SFI could be considered for improvement.

\section{Definitions}

Accurate estimates of areas of forest land and its subcategories, and growing stock volume within the subcategories, require accurate delineation of those land categories which, in turn, requires rigorous definitions and knowledge and application of those definitions. Current terminology as translated into English makes some Russian land categories difficult to distinguish and delineate. For example, lands with forest are classified as forest land or non-forest land, and forest land is further divided into land covered by forest and land not covered by forest. A reasonable question is how "land with forest" can be classified as "non-forest", and how "forest land" can have "land not covered by forest"? Most international strategic inventories rigorously define forest land with respect to multiple criteria including minimum area, minimum width, minimum tree or tree crown cover, occasionally minimum height at maturity in situ, and forest use where the latter criterion focuses on availability for harvest and excludes orchards, parks, reserves and sometimes plantations (Tomppo et al. 2010a). Further, the Food and Agriculture Organization (FAO) of the United Nations provides criteria for distinguishing multiple categories of land with varying degrees of tree cover including forest land, other wooded land, and trees outside forest (FAO 2012). Consideration could be given to increasing comparability between the Russian and FAO classification systems.

Table 3 Measurement units by plot component

\begin{tabular}{lll}
\hline Circle radius $(\mathrm{m})$ & Area $\left(\mathrm{m}^{2}\right)$ & Measurement \\
\hline 12.62 & 500 & Trees with $\mathrm{DBH} \geq 20 \mathrm{~cm}$, dead wood with diameter $\geq 6 \mathrm{~cm}$, stumps with diameter $>12 \mathrm{~cm}$ \\
5.64 & 100 & Trees with a $\mathrm{DBH} \geq 12 \mathrm{~cm}$ \\
2.82 & 25 & Trees with a $\mathrm{DBH} \geq 6 \mathrm{~cm}$ \\
$1.78($ two $)$ & 20 & Natural and artificial regeneration with height $\geq 0.2 \mathrm{~m}$ and $\mathrm{DBH} \leq 5.9 \mathrm{~cm}$, undergrowth \\
Strip $(10 \mathrm{~m} \times 1 \mathrm{~m})$ & 10 & Ground vegetation \\
\hline
\end{tabular}


Table 4 Variables, groups of variables and most labor intensive variables

\begin{tabular}{|c|c|c|}
\hline Variable group & Number of variables & Most labor intensive variables \\
\hline Sample plot description & 47 & $\begin{array}{l}17 \text { variables determined before sample plot field works } \\
30 \text { variables determined on the plot in field: } \\
\text { Relief measurements, including micro- and mezo- relief elements, } \\
\text { the steepness of the slope. } \\
\text { Soil description, including soil type, soil erosion, mechanical composition, } \\
\text { humidity, humus type, humus layer depth. } \\
\text { Tree stand characteristic, including origin, number of canopy layers, age } \\
\text { structure, type of canopy closure, stand sustainability and digression. }\end{array}$ \\
\hline Ground vegetation & 5 & $\begin{array}{l}\text { Projective cover by berries ( } 8 \text { species), medical plants ( } 54 \text { species), lichens } \\
\text { length on trees stem. }\end{array}$ \\
\hline Description of trees including dead trees & 24 & $\begin{array}{l}\text { Tree coordinates, height up to living part of crown, height up to maximum } \\
\text { diameter of crown, stem length without knots, crown ground projection, } \\
\text { tree diameter and height increment for the last } 10 \text { years, technical quality. } \\
\text { Model tree measurements: tree length, diameter, diameter increment, bark } \\
\text { width on relative tree height }(0.1,0.25,0.5 \text {, and } 0.75 \text { of tree length). } \\
\text { Dead trees: type of damage, damage location on stem and intensity. }\end{array}$ \\
\hline Measurements of stem form and wood quality & 5 & $\begin{array}{l}\text { Measurement of tree diameters from stump up to crown for stem profiling. } \\
\text { Stem divided into sections according to quality criteria (number of branches } \\
\text { per } 1 \mathrm{~m} \text {, rot, mechanical damage, etc.). }\end{array}$ \\
\hline Biodiversity estimation & 5 & $\begin{array}{l}\text { Estimated sample of } 20 \text { trees closest to plot center: species composition, } \\
\text { spacing of tree species, spacing of individual trees, diversity of diameters } \\
\text { and heights. }\end{array}$ \\
\hline Regeneration measurements & 12 & Quantity, vitality, means age, height and diameter. \\
\hline $\begin{array}{l}\text { Description of undergrowth, fruits, nuts and } \\
\text { medicine bushes and trees }\end{array}$ & 4 & $\begin{array}{l}\text { Species (46), } \\
\text { height class, } \\
\text { quantity per height class, } \\
\text { mean age. }\end{array}$ \\
\hline Deadwood (detritus) description & 15 & $\begin{array}{l}\text { Detritus type (firewood, deadwood, stamps), spacing on sample plot, species, } \\
\text { age, length, diameter, decay class, type of rot, size of rot. }\end{array}$ \\
\hline Total & 117 & \\
\hline
\end{tabular}

\section{Sampling design}

With simple random sampling as used by the SFI, simple random effects would be expected to result in a few plots being located in close spatial proximity to other plots. However, the large numbers of plots in close spatial proximity found in the Bryansk and some other regions are far too great to be attributed simply to random effects and suggest a failure to correctly implement simple random sampling (Fig. 4).

The lack of appropriate randomization is also apparent in observations of mean forest area per plot. For the total forest land area of 891.16 million ha, simple random sampling, and a total sample size of 84,700 plots, the mean forest land area represented by each plot is 10,521 ha. Although some variation around this average should be expected due to both different regional precision requirements and random effects, the variation greatly exceeds expectations for six administrative regions: the Lipetsk, Orel, and Novgorod regions, the Karelia Republic, and the Tula and Ryazan regions (Table 5). In particular, for the Lipetsk administrative region in the Forest steppe forest region with a precision requirement of $2 \%$, the mean forest land area represented by each plot was
598.3 ha, while for the portion of the Karelia Republic in the Middle taiga forest region, also with a precision requirement of $2 \%$, the mean forest land area within strata represented by each plot was 12,957.4 ha. For the four administrative regions in the Forest steppe region, all with the same $2 \%$ precision requirement, a single plot represented 598.3 ha, 730.2 ha, $743.5 \mathrm{ha}$, and $1173.0 \mathrm{ha}$. These results suggest that simple random sampling was not correctly implemented. To compensate for this apparent incorrect implementation, and thereby avoid biased estimators, additional sample plots may need to be established to complete the coverage.

To ensure complete spatial coverage, which is not necessarily achieved using simple random sampling, NFIs commonly use systematic sampling designs featuring regular grids of sample plots (Tomppo et al. 2001, 2011; Köhl et al. 2006; FAO 2009). In addition, greater efficiency can be realized with respect to travel costs if multiple sample plots are aggregated into groups in relatively close spatial proximity (Matérn et al. 1983; Ranneby et al. 1987). The primary motivation for these groups is to facilitate measurement of all plots in a group by a single field crew in a single day. Sampling designs that incorporate these features are characterized as multi-stage sampling. 


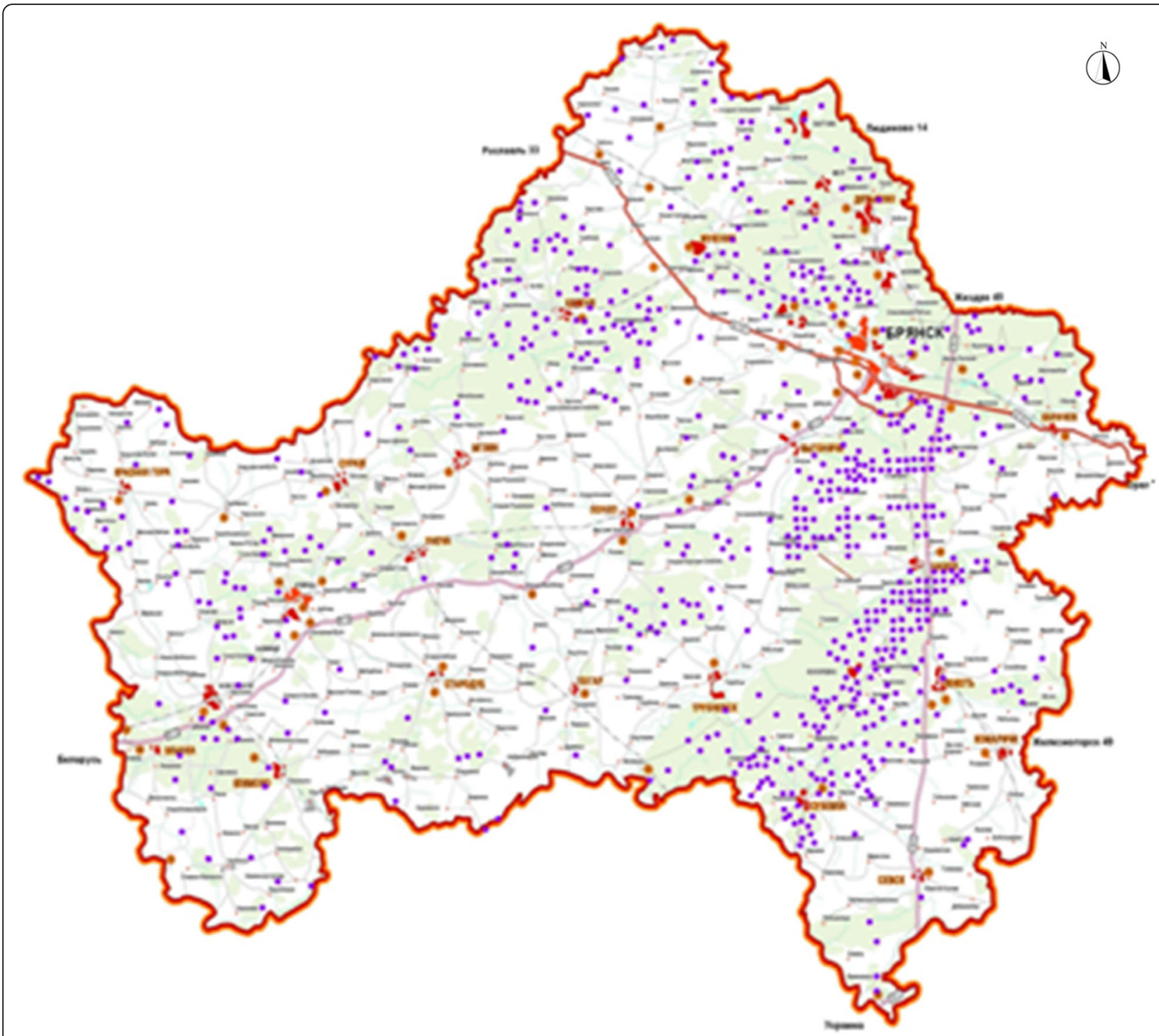

Fig. 4 Distribution of Sample Plots (violet dots) in the Bryansk Region with evidence of clumping and an uneven distribution of plots within the region

Table 5 Forest land area per plot

\begin{tabular}{|c|c|c|c|c|c|c|}
\hline Administrative region & Forest region & $\begin{array}{l}\text { Forest land } \\
\text { area (ha) }\end{array}$ & Number of strata & Number of plots & $\begin{array}{l}\text { Mean number of plots } \\
\text { per stratum }\end{array}$ & $\begin{array}{l}\text { Mean forest land area } \\
\text { per plot (ha) }\end{array}$ \\
\hline Lipetsk & Forest-steppe & $187,855.3$ & 36 & 314 & 9 & 598.3 \\
\hline Orel & Forest-steppe & $203,718.0$ & 33 & 279 & 8 & 730.2 \\
\hline \multirow[t]{2}{*}{ Ryazan } & Conifer-broadleaved & $860,543.6$ & 40 & 331 & 8 & 2599.8 \\
\hline & Forest-steppe & $193,540.9$ & 35 & 165 & 5 & 1173.0 \\
\hline \multirow[t]{2}{*}{ Novgorod } & Southern taiga & $1,692,103.7$ & 45 & 683 & 15 & 2762.8 \\
\hline & Conifer-broadleaved & $1,886,992.5$ & 46 & 500 & 11 & 3384.2 \\
\hline \multirow[t]{2}{*}{ Karelia Republic } & Northern taiga & $4,927,344.1$ & 32 & 363 & 11 & $13,574.0$ \\
\hline & Middle taiga & $4,846,053.5$ & 38 & 374 & 10 & $12,957.4$ \\
\hline \multirow[t]{2}{*}{ Tula } & Conifer-broadleaved & $260,195.0$ & 32 & 145 & 5 & 1794.4 \\
\hline & Forest-steppe & $110,774.0$ & 32 & 149 & 5 & 743.5 \\
\hline
\end{tabular}


Although multi-stage estimators are more complex than estimators used with simple random and systematic sampling designs, the positive effects with respect to travel costs can be substantial.

\section{Stratification}

Strata for the second level of stratification were based on age class, forest yield class, density class, land class, and species composition. Attributes of the second level strata were expected to be similar to the attributes of the plots assigned to the strata. However, an analysis of the first SFI results reveal that attributes for large numbers of sample plots did not closely match the attributes of the strata to which they were assigned. The degrees to which plot and strata attributes matched were analyzed for six administrative regions: the Lipetsk, Orel, and Novgorod regions, the Karelia Republic, and the Tula and Ryazan regions (Table 6). The percentages of sample plots assigned to non-matching strata varied from $10.8 \%$ for the Orel region to as great as to $46.4 \%$ for the Novgorod region. Although these non-matching stratum assignments do not induce bias into the post-stratified estimator of the mean, they reduce the effectiveness of the stratification for increasing precision.

To be effective, stratifications typically satisfy two criteria: first, within-stratum means differ substantially among strata, and second, within-stratum variances are substantially smaller than the overall variance. For some strata in the Leningrad administrative region, within-stratum variances were very large due to differences between minimum and maximum growing stock volume observations as great as $490 \mathrm{~m}^{3} /$ ha (Sinkevich 2011). Similar results were found in the Kaluga region (Moiseev and Fylipchuk 2014). For both cases, the stratifications were ineffective for reducing overall variances.

Multiple reasons can be advanced to explain the assignment of plots to non-matching strata. First, the basic unit for construction of strata is the forest compartment. Compartments are delineated for management purposes with compartment size depending on the category of forest taxation intensity. The three taxation categories, in turn, depend on the agreed level of detail and the required accuracy of forest measurements. Recommended

Table 6 Accuracy of second-level stratifications

\begin{tabular}{lll}
\hline Region & Number of plots & Matching assignment (\%) \\
\hline Lipetsk region & 272 & 60.3 \\
Orel region & 279 & 89.2 \\
Novgorod region & 1116 & 53.6 \\
Karelia Republic & 676 & 83.1 \\
Tula region & 293 & 84.3 \\
Ryazan region & 507 & 65.9 \\
\hline
\end{tabular}

compartment areas vary from 3 ha for the first category to as great as 200 ha for the third category which is usually used for remote and unused forest areas. Even the smallest compartments exhibit heterogeneity with respect to the stratification attributes. Thus, the attributes of the portion of a heterogeneous compartment that includes the $500 \mathrm{~m}^{2}$ sample plot may easily differ from the attributes from the rest of the compartment and, more importantly, from the attributes of the stratum to which the compartment and the plot are assigned. With larger compartments, the probability of such differences is even greater. This problem is further exacerbated when the compartments are poorly described. Thus, assignment of entire compartments, particularly large heterogeneous compartments, to the same stratum, exacerbates the problem of plot attributes that do not match the attributes of the stratum to which they are assigned. Additional disadvantages of using compartments as the basic units assigned to strata are that compartment boundaries are often not sharp or well-defined and that they change over time, meaning that plots may have to be reassigned to strata for subsequent SFI cycles.

A second cause for the assignment of plots to non-matching strata is that the strata may not satisfy the statistical criteria that they both cover the entire population and are thematically mutually exclusive (Cochran 1977, section 5.1; Alekseev 2013). One consequence is that a plot's attributes may closely, but not exactly, match the attributes of multiple strata. Third, non-matching stratum assignments may be due to errors in the classification of remotely sensed data and to change in the plot conditions between the plot measurement date and the date of the information used to delineate the stratum.

Fourth, for variance reduction purposes, Cochran (1977, p 134) recommends no more than 6-8 strata, while Cochran (1977, p 134), Särndal et al. (1992, pp 267, 407) and Westfall et al. (2011) recommend that the strata should be sufficiently large that 10-20 sample units are assigned to each stratum. Thus, based on the results reported in Table 5, the SFI uses an excessive number of strata and often does not satisfy the minimum sample size per stratum. Finally, construction of the second-level stratification is very labor intensive. Together, these four factors lead to the conclusion that the second-level stratification as currently designed and implemented is neither effective nor efficient.

\section{Sample size}

SFI large area estimates are intended to inform long-term strategic forest planning and do not require extreme precision. The current instructions for forest inventories in support of management planning specify that precision for growing stock volume estimates for forest management compartments can vary from 15 to 
$30 \%$, depending on the method applied. Thus, for strategic inventory purposes, the proposed target precisions for growing stock estimates by forest region, which range from 1 to $5 \%$ (Table 2), can be reduced by half or more.

\section{Plot configuration and measurements}

Plot measurement is both time consuming and laborious and is constrained by the necessity of measuring an entire plot in a single day. Multiple options may be considered for reducing the intensity of these efforts. First, the current list of 117 variables assessed per plot may be excessive given the large areas that must be inventoried. Second, the primary purpose of the temporary plots is to increase the precision of area and volume estimates for sub-regions. Thus, temporary plots do not require such detailed measurements, meaning that time consuming measurement of variables such as deadwood and ground vegetation are not necessary. Third, the proportion of temporary plots could be greatly increased, although some consideration should be given to the adverse effects on the precision of estimates of change, particularly for small areas. Fourth, Bitterlich sampling could be considered for the temporary plots if their primary purpose is to increase the precision of volume-related parameter estimates. If so, caution should be exercised when both types of plot are used for the same estimation area. In particular, caution should be exercised regarding minimum diameter and area thresholds and adequate sample sizes for types of plots. Further, data for fixed area and Bitterlich plots cannot be combined, but rather estimates for the two plot types must be calculated separately with the estimates subsequently combined using methods such as inverse variance weighting (Marin-Martinez and Sanchez-Meca 2010).

\section{Estimation}

The State Forest Register (SFR) was introduced by Article 91 of the Forest Code of 2006 and is an official collection of information on the use, protection and regeneration of forests obtained from compartment inventories and forest management operations. Specifically, the SFR includes information on the land on which forests are located; forest districts, divided into blocks and compartments; protective, exploitable and reserved forests; specially protected and delineated forest areas; quantitative and qualitative economic parameters; and the use, tending and regeneration of the forests. For remote and uneconomical forest areas, the SFR data have been out-of-date for more than 20 years and require substantial updating.

Although SFI and SFR estimates are not completely comparable, their differences for both area and growing stock volume are considerable (Table 7). The "area of forest land" and the "area covered by forest", both according to the SFR, differ only slightly from SFI estimates, reflecting current changes in the definitions of these land categories. However, SFI estimates of areas covered by coniferous species deviate from SFR estimates by $14.84 \%$ for the Orel region to $-40.9 \%$ for the Tula region. Relative differences in growing stock volume estimates are even greater with a maximum of 94.92\% for the Novgorod region, $40.9 \%$ for coniferous stands in the Lipetsk region and $1405.26 \%$ for mature and over-mature stands in the Novgorod region. In addition, while the area covered by coniferous species for the Novgorod region declined by $19.93 \%$, growing stock volume increased by $94.92 \%$ in total, by $29.03 \%$ for coniferous stands and by $1405.26 \%$ for mature and over-mature stands. Deviations between growing stock volume estimates were greatest for mature and over-mature stands, a finding of considerable concern because these estimates serve as the basis for allowable cutting level calculations and, therefore, may lead to quite erroneous management decisions.

Because the SFI estimates of important forest parameters related to total growing stock volume and growing stock volume for some tree species differ so substantially from the current SFR estimates, the SFI estimates cannot be recommended for use in forest management planning. Further, a close relationship between the area represented by one sample plot and the deviation of

Table 7 Deviation of State inventory results from State Forest Register data, considered as reference data, \%

\begin{tabular}{|c|c|c|c|c|c|c|}
\hline \multirow{2}{*}{$\begin{array}{l}\text { Regions of the } \\
\text { Russian Federation }\end{array}$} & \multicolumn{3}{|l|}{ Area } & \multicolumn{3}{|c|}{ Growing stock } \\
\hline & Forestland & Covered by forest & Conifers & Total & Conifers & Mature and over mature \\
\hline Lipetskregion & 0.3 & 0.2 & No data & 37.7 & 40.9 & No data \\
\hline Orelregion & -0.08 & -0.48 & 14.84 & 3.32 & 14.48 & 52.91 \\
\hline Ryazan region & 1.87 & -1.74 & -25.25 & 28.3 & 21.63 & 111.03 \\
\hline Novgorodregion & 3.51 & 3.56 & -19.93 & 94.92 & 29.03 & 1405.26 \\
\hline KareliaRepublic & -0.24 & 0.53 & -26.77 & 39.83 & 26.13 & - \\
\hline Tularegion & 3.3 & 2.9 & -40.9 & 86.6 & 29.5 & 252.1 \\
\hline
\end{tabular}


growing stock estimates for mature and over-mature tree stands is evident (Tables 5 and 7).

The greater the area represented by one plot, the greater is the deviation of the growing stock estimates from the reference data (Fig. 5). The coefficient of determination for this relationship is $94 \%$.

\section{Timing}

SFI progress has been very slow, a discouraging result when considering the huge forested area that must be inventoried. The original plan was to establish 84,700 ground sample plots during the 10-year or perhaps 15 -year first inventory cycle which started in 2007. However, 10 years after initiation, only $52 \%$ of the forest area had been inventoried and by 2020 , only $80 \%$ is expected (Table 8).

In 2017, the SFI targets were revised downward (Table 8), and in 2018, a further decision was made to complete the first SFI cycle by 2020 by establishing only 68,287 permanent sample plots instead of the 84,700 as initially planned, a reduction of 16,413 (19.4\%) sample plots. Work completed by 2017 and plans for 2018-2020 with respect to area inventoried are summarized in Table 9.

For 2018-2020, the last three years of the cycle, SFI plans are to inventory the remaining area of 715.6 million ha using 11,000 sample plots which will produce mean area of $65,054.5$ ha per sample plot, whereas for 2007-2017, the first 10 years of the cycle, an area of 468.9 million ha was inventoried using 57,300 sample plots which produced mean area of 8126.5 ha per sample plot. Thus, for 2018-2020, a very large area will be inventoried using a relatively small number of plots which leads to the conclusion that the final estimates may lack adequate precision.

Generally, revision of the SFI time schedule and its sharp finalization suggests ineffectiveness of the current sampling design. In addition, plot measurement dates within the same

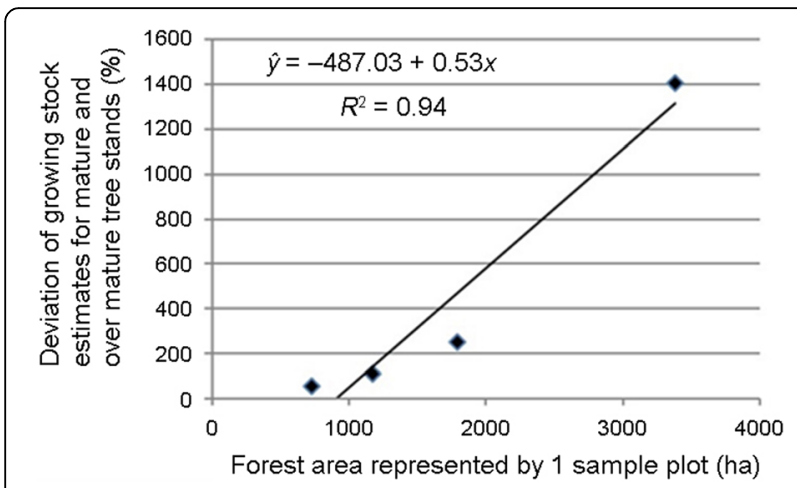

Fig. 5 Dependence between deviation of growing stock estimates for mature and over mature tree stands and forest area represented by each sample plot forest region may vary by as much as 10 years. For example, the inventory of the Conifer-broadleaved (mixed) forest region of the European part of the Russian Federation (Table 2, No. 5) has almost been completed, except for the Moscow region and the Republic of Udmurtia. Yet the first measurements for the Bryansk region within this forest region have been available since 2007. Thus, accommodation of the large differences in plot measurement dates for the entire Conifer-broadleaved (mixed) forest region will require special estimation techniques. One result of organizing the SFI by administrative unit but using a sample design developed for districts is that no forest district has yet been fully inventoried.

\section{Remote regions}

The Russian Federation includes large forested areas classified as "hard-to-reach" (Fig. 6) based on six criteria: (1) the density of permanently available transportation including water ways is less than $0.05 \mathrm{~km}$ per $1 \mathrm{~km}^{2}$; (2) the terrain is very rugged; (3) areas include slopes exceeding 30 degrees; (4) forested areas occupy less than $20 \%$ within bogs, swamps, stony places and other open territories as well as on islands within large water bodies; (5) forests areas damaged by fires, storms, insects are exceed 500 ha; and (6) shrub land. The total land area on which forests are located is 1183.3 million ha, of which approximately 920 million ha are "hard-to-reach" or "reserved forests" (Fig. 6). Appropriate inventory methods for such areas have not yet been developed with the result that the completion year for the entire first SFI cycle is not yet known. The most efficient approach for inventorying these areas may be to use double sampling for stratification (Cochran 1977, Section 12.2; Tomppo et al. 2010b, 2014).

With this method, the inventory is conducted in two phases. In the first phase, a regular grid of photo plots is used to estimate the areas of pre-selected strata; in the second phase, ground plots are measured at the locations of a subset of the first-phase photo plots. Factors such as accessibility can be used as the basis for strata without inducing bias into the estimators.

\section{Recommendations and conclusions}

Assuming that the SFI objective is to report accurate and precise strategic estimates on a continuous basis, critical review of the methods is recommended. First, a sampling design featuring systematically distributed clusters of plots would improve coverage and increase efficiency. In addition, with a systematic sampling design, the plots could be organized into interpenetrating panels whereby the entire country is systematically inventoried each year but at a greatly reduced sampling intensity (McRoberts 2001; Fig. 1; Tomppo et al. 2011). For example, if an inventory cycle of 10 years is used, a systematic sample of 
Table 8 SFI targets according to the State Programs of Forestry Development (State Program, 2014 and 2017)

\begin{tabular}{|c|c|c|c|c|c|c|c|c|}
\hline Year & 2013 & 2014 & 2015 & 2016 & 2017 & 2018 & 2019 & 2020 \\
\hline $\begin{array}{l}\text { Expected Coverage of forest area by the SFI according State Programs } \\
2014 / 2017(\%)\end{array}$ & 21/19.6 & $29 / 23$ & $39 / 26$ & $44 / 29$ & $52 / 34$ & $63 / 40$ & $71 / 48$ & $80 / 58$ \\
\hline Deviation between State Programs 2014 and 2017 & -1.4 & -6 & -13 & -15 & -18 & -23 & -23 & -22 \\
\hline
\end{tabular}

$10 \%$ of the plots in each region would be measured each year. With an interpenetrating panel sampling design, annual estimates, albeit less precise estimates, could be calculated each year to quickly assess the effects of local disturbances such as fire, wind storms, drought, and insect outbreaks. Combining the data for the 10 annual panels would produce estimates with the required precision. Also related to the sampling design, the target precisions as reported in Table 2 may be appropriate for management inventories but are almost certainly excessive for a strategic inventory such as the SFI, thus leading to the possibility of reducing within-region sample sizes.

Second, the ineffectiveness of the second level of stratification can be attributed to two factors, the large number of strata and the assignment of entire management units to the same stratum. First, the large number of strata results in small sample sizes per stratum. Aggregation of the SFI's 49 s-level strata into a smaller number in the range of 5-10 would likely resolve most issues related to variation in forest area represented by individual plots. In addition, aggregation of similar smaller strata into larger strata increases the sample size per stratum, thereby reducing the variances of the estimates of both within-stratum means and the overall mean, while likely having little effect on the estimate of the overall mean itself. Second, the adverse effects of assignment of entire management units to strata would be alleviated by the more common practice of assigning plots to strata without regard to the management unit in which the plot is located. Third, estimators that do not conform exactly to complex stratifications are subject to considerable bias. Thus, aggregation of the SFI's current 49 second-level strata into a smaller number and assignment of plots, rather than management units, to strata would contribute substantially to more efficient and precise estimation.

Third, greater efficiency could be achieved by reducing the large number of variables (117) that have to be measured on each plot. Eliminating redundant variables would result in greater assessment efficiency, such that an entire cluster of plots can be assessed in a single day without losing essential information.

Fourth, multiple techniques, most of which incorporate remotely sense data, could be used to facilitate inventories of remote and "hard-to-reach" forest areas. First, double sampling for stratification featuring first-phase photo assessments and second-phase ground measurements have a long history for large area forest inventories (Bickford 1952, 1960). Second, multiple remote sensing-assisted approaches such as post-stratification using satellite-based strata can increase precision without increasing sample sizes (McRoberts and Tomppo 2007; McRoberts et al. 2010). Overall, remotely sensed data should be used to augment, rather than replace, ground sample data. Total reliance on remotely sensed data precludes acquisition of data for constructing allometric volume models, potentially induces bias and reduces precision for statistical estimators, and may require complex procedures to account for interpretation and classification uncertainty (McRoberts et al. 2018).

Fifth, land use categories and sub-categories used in the Russian Federation are confusing for anyone not extremely familiar with the classification system. For example, the distinctions between forest land, land with forest, and land covered by forest are not at all intuitive. While acknowledging the historical and political background for the current category definitions, from an international perspective, a revision of the terminology to make it much more compatible with the terminology of international organizations such as FAO would be welcome and beneficial. At the least a cross-walk could be developed between the Russian land use categories and subcategories and the categories and subcategories used by FAO (FAO 2018).

Before beginning field work for the next SFI cycle, these recommendations should be discussed, more fully

Table 9 Summary of completed (2007-2017) and planned work (2018-2020)

\begin{tabular}{|c|c|c|c|c|c|c|c|}
\hline \multicolumn{2}{|c|}{ Combined in 2007-2017 } & \multicolumn{2}{|l|}{ Plans for 2018} & \multicolumn{2}{|l|}{ Plans for 2019} & \multicolumn{2}{|l|}{ Plans for 2020} \\
\hline $\begin{array}{l}\text { Area, millions } \\
\text { of hectares }\end{array}$ & $\begin{array}{l}\text { Number of sample } \\
\text { plots, thousands }\end{array}$ & $\begin{array}{l}\text { Area, millions } \\
\text { of hectares }\end{array}$ & $\begin{array}{l}\text { Number of sample } \\
\text { plots, thousands }\end{array}$ & $\begin{array}{l}\text { Area, millions } \\
\text { of hectares }\end{array}$ & $\begin{array}{l}\text { Number of sample } \\
\text { plots, thousands }\end{array}$ & $\begin{array}{l}\text { Area, millions } \\
\text { of hectares }\end{array}$ & $\begin{array}{l}\text { Number of sample } \\
\text { plots, thousands }\end{array}$ \\
\hline 468.9 & 57.3 & 216.0 & 4.6 & 239.8 & 4.2 & 259.8 & 2.2 \\
\hline
\end{tabular}




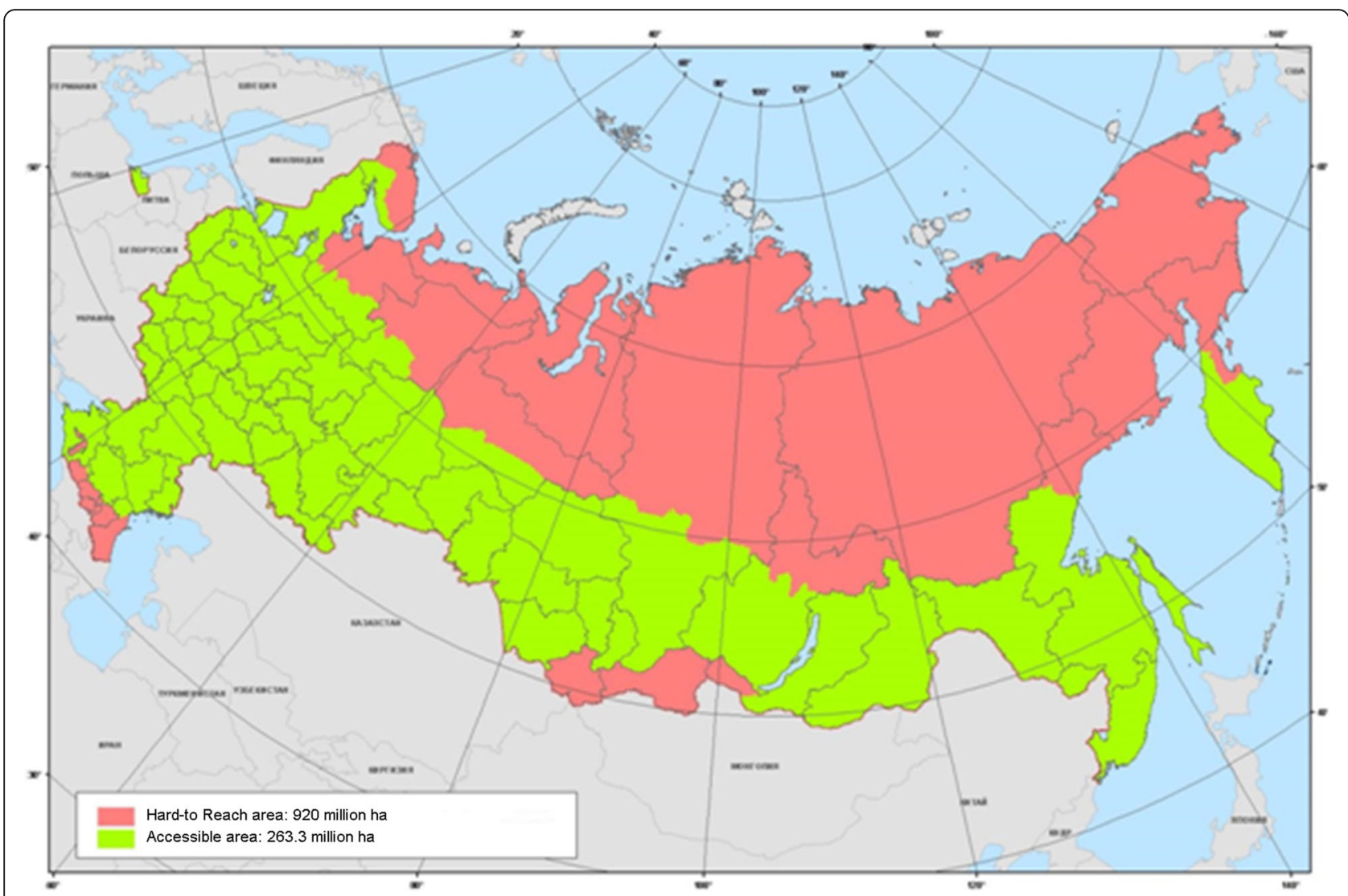

Fig. 6 Approximate areas of hard-to-reach (red: 920 million ha) and accessible (green: 263.3 million ha) forests

developed, published and generally accepted by the professional community. The resulting new strategy should produce more accurate, more precise, and more timely estimates of Russian forest resources. In addition, strategic management of the forest sector of the economy would be improved, and international reporting would be facilitated.

\section{Abbreviations}

FAO: Food and Agriculture Organization; NFI: national forest inventory; SFI: State Forest Inventory; SFR: State Forest Register

\section{Acknowledgements}

Not applicable.

\section{Funding}

Not applicable.

\section{Availability of data and materials}

Data are not available due to proprietary nature of some information.

\section{Authors' contributions}

AA jointly conceived the study, provided data, consulted on analyses, and cowrote the paper. ET jointly conceived the study, consulted on analyses, and cowrote the paper. REM consulted on analyses and co-wrote the paper. KVG jointly conceived the study, consulted on analyses, and co-wrote the paper. All authors read and approved the final manuscript.

Ethics approval and consent to participate Not applicable.

\section{Consent for publication}

Not applicable.

\section{Competing interests}

The authors declare that they have no competing interests.

\section{Author details}

'Department of Forest Inventory, Management and GIS, Saint-Petersburg State Forest Technical University, Institutsky per., 5, 194021 Saint-Petersburg, Russia. ${ }^{2}$ Department of Forest Sciences, University of Helsinki, FI-00790 Helsinki, Finland. ${ }^{3}$ Department of Electronics and Nanoengineering, Aalto University, Fl-00076 Aalto, Finland. ${ }^{4}$ Northern Research Station, USDA Forest Service, 1992 Folwell Avenue, Saint Paul, MN 55108, USA. ${ }^{5}$ Burckhardt Institute, University of Göttingen, 37077 Göttingen, Germany. ${ }^{6}$ Department of Forest and Wood Science, University of Stellenbosch, Stellenbosch, South Africa.

Received: 8 November 2018 Accepted: 19 February 2019

Published online: 08 March 2019

\section{References}

Alekseev AS (2013) Experience in forest inventory by sampling method and modern problems of national forest inventory system development. State Forest Register, State Forest Inventory and Forest Management: Materials of 3-d International Scientific-practical Conference, Novosibirsk, 29 November-1 December 2012. Moscow «Roslesinforg», pp 92-96

Antanaitis V, Repshis J (1973) The experience of inventory forests of Lithuania by mathematical and statistical methods. Forest Industry, Moscow, p 102 (in Russian)

Bechtold WA, Patterson PL (2005) The enhanced forest inventory and analysis program - national sampling design and estimation procedure. Gen. Tech. Rep. SRS-80, Ashville, NC: U.S. Department of Agriculture, Forest Service, Southern Research Station, p 85 
Bickford CA (1952) The sampling design used in the forest survey of the northeast. J For 50:290-293

Bickford CA (1960) A test of continuous inventory for National Forest management based upon aerial photographs, double sampling, and remeasured plots. In: Anonymous (ed) Proceedings of the Society of American Foresters Meeting. San Francisco, 15-19 November 1959, pp 143148

Cochran W (1977) Sampling techniques, 3rd edn. John Wiley \& Sons, New York, Chichester, Brisbane, Toronto, Singapore, p 442

FAO (1948) Forest resources of the world. Unasylva 2(4)

FAO (2009) National forest monitoring and assessment. Document NFMA 37/R. Rome:220

FAO (2012) FRA 2015 Terms and definitions. Forest resources assessment working paper 180. Food and Agriculture Organization of the United Nations, Rome. http://www.fao.org/3/ap862e/ap862e00.pdf

FAO (2018) Global Forest Resources Assessment 2020. Terms and definitions. FAO forestry department Viale delle Terme di Caracalla Rome 00153, Italy. http:// www.fao.org/3/l8661EN/i18661en.pdf

Federal Ministry (2006) Survey Instructions for the second national forest inventory in Germany (2001-2002). Federal Ministry of Food, Agriculture and Consumer protection, Bonn, p 110

Fedosimov AN (1986) Forest inventory by sampling method. Forest industry publishing, Moscow, p 192 (in Russian)

Fedosimov AN, Anisochkin VG (1979) Sampling taxation of forest. Forest industry publishing, Moscow, p 172

Gabler K, Schadauer K (2008) Methods of the Austrian forest inventory 2000/02origins, approaches, design, sampling, data models, evaluation and calculation of standard error. BFW-BERICHTE 142:121

Holmgren P, Persson R (2002) Evolution and prospects of global forest assessments. Unasylva 53:3-9

Kangas A, Maltamo M (2006) Forest inventory: methodology and applications. In: von Gadow K, Pukkala T (eds) Managing Forest ecosystems, Vol. 10. Springer, p 377

Köhl M, Magnussen S, Marchetti M (2006) Sampling methods, remote sensing and GIS multisource forest inventory. Springer-Verlag, Berlin, Heidelberg, p 376

Land Fund of the Russian Federation (2013) Federal Service on state registration, cadaster and cartography. Moscow:694

Lithuanian National Forest Inventory (2003) Sampling design, methods, results (1998-2002). Kaunas, Lithuania, p 254

Marin-Martinez F, Sanchez-Meca J (2010) Weighting by inverse variance or sample size in random effects meta-analysis. Educ Psychol Meas 70(1):56-73

Matérn B, Ranneby B (1983) Variational structure in forests. Implications for sampling. Forest inventory for improved management. In: Proceedings of the IUFRO subject group 4.02. Helsinki, 5-9 September, vol 1983, pp 1-10

McRoberts RE (2001) Imputation and model-based updating techniques for annual forest inventories. For Sci 47(3):322-330

McRoberts RE, Stehman SV, Liknes GC, Næsset E, Sannier C, Walters BF (2018) The effects of imperfect reference data on remote sensing-assisted estimators of land cover class proportions. ISPRS J Photogramm 142:292-300

McRoberts RE, Tomppo EO (2007) Remote sensing support for national forest inventories. Remote Sens Environ 110:410-419

McRoberts RE, Tomppo EO, Næsset E (2010) Advances and emerging issues in national forest inventories. Scand J Forest Res 25:368-381

Moiseev BN, Filipchuk AN (2014) The problems of stratified sampling representativity in state forest inventory report for Kaluga region. Forestry Information 4:34-38

State program (2014) "Development of forestry in the years 2013-2020", Version by 15 April 2014. http://www.mnr.gov.ru/docs/gosudarstvennye_programmy/ 130042/

State program (2017) "Development of forestry in the years 2013-2020". Version by 31 March 2017. http://www.mnr.gov.ru/docs/gosudarstvennye_ programmy/postanovlenie_pravitelstva_rossiyskoy_federatsii_ot_30_marta_ 2018_q_370_o_vnesenii_izmeneniy_v_gosud/

Ranneby B, Cruse T, Hagglund B, Jonasson H, Sward J (1987) Designing a new national forest survey for Sweden. Studia Forestalia Suecica 177:29

Särndal C-E, Swensson B, Wretman J (1992) Model assisted survey sampling. Springer, Heidelberg, p 694

Sinkevich AE (2011) Methods of determination of forest quantitative and qualitative characteristics in state forest inventory methodology. Proceedings of Saint-Petersburg Forest Technical Academy 195:13-21
Tomppo E, Gschwantner T, Lawrence M, McRoberts RE (2010a) National Forest Inventories. Pathways for Common Reporting. Springer, Heidelberg, p 612

Tomppo E, Heikkinen J, Henttonen HM, Ihalainen A, Katila M, Mäkelä H, Tuomainen T, Vainikainen N (2011) Designing and conducting a forest inventory - case: 9th National Forest Inventory of Finland. In: von Gadow K (ed) Managing Forest ecosystems. Springer, Heidelberg, p 270

Tomppo E, Korhonen KT, Heikkinen J, Yli-Kojola H (2001) Multi-source inventory of the forests of Hebei forestry bureau, Heilongjiang. China Silva Fenn 35(3): 309-328

Tomppo E, Malimbwi R, Katila M, Mäkisara K, Henttonen HM, Chamuya N, Zahabu E, Otieno J (2014) A sampling design for a large area forest inventory: case Tanzania. Can J For Res 44(8):931-948

Tomppo E, Schadauer K, McRoberts RE, Gschwantner T, Gabler K, Ståhl G (2010b) Introduction. In: Tomppo E, Gschwantner T, Lawrence M (eds) National Forest Inventories - pathways for common reporting. Springer, Heidelberg, pp 1-18

Westfall JA, Patterson P, Coulston JW (2011) Post-stratified estimation: withinstrata and total sample size recommendations. Can J For Res 41:1130-1139

Zon R (1910) The forest resources of the world. United States Department of Agriculture, Forest Service bulletin no. 83. In: Government printing Office,Washington D.C

\section{Submit your manuscript to a SpringerOpen ${ }^{\circ}$ journal and benefit from:}

- Convenient online submission

- Rigorous peer review

- Open access: articles freely available online

- High visibility within the field

- Retaining the copyright to your article

Submit your next manuscript at $>$ springeropen.com 